\title{
SPECIFICITY OF THE FIGURATIVE-DRAMATURGIC INTERACTION OF THE MUSICAL AND VERBAL-TEXT CONCEPTS IN THE WORKS OF ARTEMY VEDEL
}

\section{Ihor Tylyk}

PhD in Art criticism, Associate Professor; ORCID: 0000-0003-2896-631X; e-mail: tilik1968@ukr.net Kyiv National University of Culture and Arts, Kyiv, Ukraine

\section{Abstract}

The purpose of the article: to highlight one of the still insufficiently researched aspects of the studies about Artemyi Vedel - the specific relation between the musical and verbaltextual peculiarities of the spiritual and choral works by $A$. Vedel in the sense of their dramatic development.

The methodology of the research is based on the combined use of universal methods of scientific knowledge, in particular, induction, deduction, historical method, cultural reconstruction, etc., the use of which makes it possible to optimally reveal the essence of the studied problems.

The scientific novelty of the study lies in the fact that for the first time in modern musicology, the specifics of the interaction of musical and verbal-text series of spiritual and choral works by $A$. Vedel at the intersection of several heuristic projections, in particular, structuralist, psychological, religious and philosophical are considered.

Conclusions. The works of A. Vedel is a complex and multi-aspect phenomenon, the essence of which is revealed through the prism of correspondence of verbal-textual and musical image.

Keywords: correlation of musical and verbal-text concepts; the spiritual and choir heritage of A. Vedel; religious and philosophical aspect; artistic perception; allegory; metaphor

\section{Introduction}

At the turn of the epochs, the problem of comprehending the new through the prism of the old, time-honored and sanctified tradition becomes more and more acute. And this is not surprising, because a person, both spiritual and thinking being, exists within a certain chronotopic range that acquires the characteristics of real space-time categories only in connection with the present and the past. As known, this connection occurs in art by reflection of the artist's own personality and manifests itself through the subjective attitude of the artist to the realities of being, expressed in their specific cultural and historical course.

Perhaps the most subjectively and meaningfully this process is reflected in music. This is due not only to the fact that music as art operates with images that 
are not subject to adequate rationalistic interpretation. It has another reason: the architectonics of the musical space in most capaciously accumulates and reproduces the multiplicity of hidden semantic subtexts, opening before the composer the inexhaustible possibilities for revealing the sophistication of human being in all its incomprehensible irrational-existential essence. Much contributing to this is the fact that music, unlike, painting or architecture, is an evolving art, like human life, within the rigidly regulated framework of a particular temporal organization. That is why the determining factor, which characterizes the forms and means of coordination of musical matter in the system of the temporal continuum, is the procedurality, expressed in a specific piece of music by the peculiarities of its dramatic expansion.

\section{The purpose of the article}

To highlight one of the still insufficiently researched aspects of the studies about Artemyi Vedel - the specific relation between the musical and verbal-textual peculiarities of the spiritual and choral works by A. Vedel in the sense of their dramatic development.

\section{Presentation of the main material}

One of the factors in the process of expanding musical dramaturgy is the verbalpoetic text and the linked to it allegoric associations. Taking its origins from prehistoric strata of cultural evolution, allegory reflects the process of the author's rethinking of real-world phenomena by means of artistic vocabulary, thus translating the semantic meaning of a particular cultural-historical phenomenon into the projection of the author's emblematic perception. Particularly significant is the period of rapid development of allegorical-metaphorical thinking in the time of European Baroque, when the ancient, religious-mystical and folk-magical layers of artistic reflection interacted in a single paradoxical alloy based on the allegorical principle.

Similar processes, although largely original in their mental specificity, can be traced in the culture of Ukrainian Baroque. According to A. Makarov, a prominent researcher of Ukrainian Baroque, "... it was the honor of the mythologema to play a leading role in the process of intention of Ukrainians in the XVII century to new spheres of conditional artistic thinking. Owing to their hidden spiritual energy, they transferred their imagination to the still unknown world of the cultural interests of antiquity. They have made it easier to get acquainted with the amazing depths of wisdom of past centuries" (Makarov, 1994, p. 230).

The well-known Kyiv-Mohyla Academy has played a significant role in reaching these depths of wisdom for more than two centuries. It was not only unique in its role and important educational center of the whole Eastern Europe, but also a real scientific and artistic laboratory, where the desire for knowledge was always combined with the search for the hidden mystical meanings lurking behind the outer material layer of the sophistication of the earthly life. A key element in this quest was to decipher and comprehend the allegorical content of the Holy Scripture. Exactly in this atmosphere was formed the worldview and talent of a whole number of prominent Ukrainians in culture 
and art, and among them it is necessary to mention the figure of the brilliant Ukrainian composer of the second half of XVIII century, Artemy Vedel (1767-1808). The Vedel's understanding of the psalm allegory is based on a centuries-old stratum of Eastern Christian, in particular Byzantine tradition that for a long time was the basis for the Ukrainian cultural environment. The wide field of life situations that build the plot of the architectonics of the psalms enabled the composer to find a personal reading of biblical images, filling them with his thoughts, moods, and analogies. The role of allegorical associations increased, combined with the re-emphasis of verbal image-symbolic complexes. Thus, in the process of individual rethinking, the canonical text was enriched with new personalized meanings, projected onto the real aspects of life's problems.

We can assume that Vedel had at least two ways in interpreting the psalm text (biblical allegory) and bringing it into the plane of the conceptual apparatus of musical vocabulary. The first one was focused on the ascetic patristic tradition, being based on "immersion in yourself", in the world of subjective religious-mystical moods and experiences. However, they should be expressed not so much through emotional reflection, but through detachment from the external, the secondary, in the name of the essential, that is, to find expression in the process of achieving a special state of spiritual harmony, wherein the individual is able to enter into a mystical "resonance" with the godhead. The second way, that is, according to our opinion, the most characteristic regarding Vedel's work, is focused on the interpretation of the canonical text as a means of reflecting the emotional and psychological experiences that has every person. This approach takes the biblical theme beyond a purely sacred understanding, providing it with a universal humanistic sound. At the same time, the sphere of religious feelings embodied in the work of the composer acquired a distinct individualization associated with the reproduction of the multifaceted spectrum of various psychological states inherent in the author's worldview.

Therefore, it is logical to assume that particularly the individual-psychological traits of Vedel's personality, his specific worldview was that determining criteria, which led to the selection of specific canonical texts as a dramatic basis for artistic intentions. In most cases, the composer creates his spiritual concerts based on the needs of his own soul. This, in particular, is indicated by the memoirs of the composer's contemporaries. Thus, according to V. Zubovskyi, that is cited by V. Ascochenskyi in his monograph, Vedel not only knew all the psalms by heart, but also thought, to a certain extent, in psalm images, singing with tears in his eyes certain psalm fragments (episodes) that were in harmony with his experiences and mood at that particular moment of life (Askochenskiy, 1856, p. 376). That is why, in most of the artist's works we see the prevalence of minor chords that probably most adequately reproduces the persistent psychological states of Vedel himself.

This makes it possible to draw associative parallels between the imaginative thinking of the artist and the deep layers of the Ukrainian "repentant" tradition, in which the situational aspect of the emotional experience is dominant. It is through the prism of the latter that the composer's desire to show the states of heightened dramatism, depression, despair, and frustration, which, embodying the tragedy aspect of earthly existence, fill the human life with the suffering pathos of harmony between the spiritual life of the individual and the environment. In this context, it is revealing that Vedel 
portrays the spiritual world of a human not from the standpoint of the rationalistic foundations of the Enlightenment with his unconditional recognition of the victory of intelligence and good over darkness and evil. But he does it from the standpoint of the Baroque worldview with its inherent awareness of the fatality of human existence in a constant two-sided duel in the personality, as a mysterious and contradictory substance, the result of an incomprehensible combination of spirit and flesh, death and life. This fills the composer's creativity with particular philosophy and tragic paradox, allowing him to project the universal comprehensiveness of the psalm allegory into a plane of focused emotional experience, interpreted from the perspective of one's own emotional experience. Thus, Vedel's sentiments related to the artistic rethinking of canonical images are re-interspersed in the system 'author-listener', being actualized in a particular form of individual-collective empathy, where multiplicity appears as the sum of individualities. This process reveals the specific essence of Vedel's creativity as an open system of deeply personal and at the same time universal in its accessibility expression in the context of which the biblical-allegorical 'urtext' and its figurative symbolism acquire a qualitatively new semantic color.

With his work, Vedel seems to say, "This is mine, personally experienced and afflicted". At the same time, the composer is clearly aware that the 'his' belongs not only to him, but also to many other people, for whom he expressed all that they felt in their souls (each in their own way), but were not able to express through art. Perhaps this is the reason for the almost mystical, legendary piety with which the composer's contemporaries and descendants related to his work, as well as the degree of emotional influence on the listeners observed during the performance of Vedel's works (Askochenskyi, 1856; Petrushevskyi, 1901). This was greatly facilitated by the fact that Vedel's music enabled the listeners to directly engage in the process of religious and artistic catharsis in its most accessible and, at the same time, aesthetically perfect form. Thus it brings out the phenomenon of aesthetic experience beyond the banal perception. Thereby it placed every Vedel's work in the rank of an event of extraordinary significance.

Guided by the demands of the democratic strata of society, Vedel actually satisfied with his creativity the aesthetic needs of the Ukrainian mass consumer ${ }^{1}$. He fulfilled with a meaning that to some extent he was involved in the system, so called 'mass culture' of his time, based on the flexible parity of secular and religious world, expressed through the complex interaction of various artistic manifestations, actualized both in the musical genre (psalm-canticles, solo-singings, romances), and literary-theatrical genre (evagation, biography, psalms, elements of schools theater, vertep dramas). It is in this plane that parallels with the real musical life are most clearly expressed in the artist's creative work, tracing the connections with the folk and professional art of that time. At the same time, the composer's reliance solely on canonical textual material led to a high degree of metaphorical expression, which was expressed in the polysemantics of latent meanings that was traditional for baroque thinking, through which the author translated certain biblical images into the sphere

${ }^{1}$ This is due to the variety of means used by the composer in the process of composing text material. For example, in those cases where Vedel proceeds from the prerequisites of the dramatic development through a single storyline, the composer chooses as a basis the full text of the psalm, such as in Concert \# 3 "How Long, Lord, Forget Me." Where he seeks to reflect the multifaceted combination of different emotional states, he forms a text series on the principle of a kaleidoscopic ("mosaic") synthesis of disparate psalm elements. 
of personal or social (national liberation) problem. It is noteworthy that in different periods of creativity the composer's attitude to the role of text and music in the system of figurative architecture was unequal, reflecting qualitative changes in the author's world perception.

For example, in most of his early works, Vedel builds the concert dramaturgy based on a gradual unfolding of musical material presented as an illustration to the canonical text. At the same time the components of the dramaturgical complex are in 'harmonious equilibrium', covering both the primary plot-allegorical essence of the psalm image and the emotional attitude to it from the standpoint of the author's world perception. An example of this is could be the concert \# 1 in A-minor ('On the Rivers of Babylon'). Dramaturgically resolved as a multi-part cycle work having in total 11 parts, the concert consists of small "mosaic" episodes, where each could be considered - in a purely artistic aspect - as a separate, to some extent autonomous, construction. At the same time, the unity of the dramaturgical unfolding is carried out in concert primarily due to the plot determinism of the psalm-strophic architectonics, where each subsequent stage of development seems to sprout from the previous one. The integrity of the single compositional construction of the concert is based on the interconnectedness of the liturgy, where music, as well as architecture, decor, etc., is only one of the components of the sacred space.

Thus, the mentioned concert, like the practice of school theater, performs an illustrative function of musical concepts, which seems to be "soldered" (mounted) in the context of the church service with its paraphernalia (priests' utterances, censing, icon painting), loosing beyond the service its artistic integrity and compositional self-sufficiency. In the later concerts, Vedel deliberately avoids direct dependence on textual dramaturgy; This leads to a misbalance of harmony in the system 'concert sacred act', which is why later Vedel concerts begin to 'fall out' from the context of liturgical practice that partly was the reason of accusations of the composer's creativity in excessive theatricality and 'fantasticality'. Instead, the tendency to personalize individual dramatic elements, and often-entire compositional layers, is intensified. The outward manifestation of these processes is the deepening of figurative contrasts between the main levers of Vedel's dramaturgy - ensembles and tutti. Unlike the early period of the composer's creativity, where 'tutti' had no semantic implication of their own, playing, in line with the traditions of ancient drama, the role of the collective generalization of the thought or mood exhibited before, in the later works of Vedel the 'tutti' episodes are increasingly filled with original allegorical sense, quite understandable only in the context of hidden plot metaphors.

An example of this is, inter alia, the 'tutti' part in the concert No. 3, "Oh, Lord, Forget Me", where the use of general choral singing, especially in Part I, is going beyond the ordinary choral generalization, embodying the collective impersonation of societypatriotic motives. In this case, two dramatic plans are clearly traced. The first, expressed in various ensemble constructions, shows the story development at the individualpsychological level, and the second is a social projection of the author's personal moods, passed through the prism of national interests of the Ukrainian ethnic group. At least we get the impression that the composer consciously seeks to emphasize the ensemble antiphonicity of the timbre and register layers, investing in this juxtaposition 
not so much aesthetic as certain allegorical overtones. In order to test the likelihood of this assumption, we try to analyze the architectonics of the first part of the concert from the perspective of the structural interaction of text and music concepts.

According to the definition by N. Gerasimova-Persidska (1997), given about the Ukrainian tradition of part-songs and motets in the XVI-XVII centuries, "...there are two variants in the combination of text and music: the first one - the text is unfolded sequentially, as in reading. That is the 'narrative' type. The second variant is when the text has repetitions of different levels and scales, based on which a new structure emerges, which can be defined as a 'poetic' type. "Narrative" is more often associated with large texts, "poetic" - with smaller texts, although there are some exceptions. However, in general, most works are partly a "narrative", and partly a "poetic" type of structure. "Narrative" type is an "urtext", the "poetic" - is a new version created by the will of the composer, who continued and developed the possibilities of the "urtext"..." (p. 16). The features of the music-text organization, outlined by the researcher, are largely also traced in the structure of Vedel's concert \# 3. In particular, it finds expression in structural alterations, expressed through the fragmentation of the strophic architectonics of the psalm by repeating separate lines, phrases, individual words.

For example, the opening line of the first verse of the 12th Psalm acquires, in the artistic design of Vedel, the appearance of several semantic segments, presented in simultaneous or diachronic projection. The first of these, on the basis of which the composer constructs the main intonation-rhythmic formula of the first section, in the context of 'poetic' re-transformation of the psalm 'urtext'-material acquires signs of rhetorical ambiguity. The embossed intonation pattern of this two-stroke construction with its wavy graphics creates the effect of a paradoxical spontaneity of expression, full of moods of doubt and hope. This is also facilitated by the specificity of the structural organization of the text, where the interrogative phrase "How long" is repeated twice: before and after the address - "How long, my Lord, how long?"

At the same time, as we can see, a symmetrical structure of the interrogatory type emerges, in which the potential energy of the subsequent dramatic development is concentrated. At the same time, the absence of signs of a strong-willed imperative principle, expressed in a verb form, suggests that the composer put in this form a certain shade of epigraphy, the statics of which, expressed in parallel sixth chord movement in viola and tenor, is compensated by contrast-counterpoint in the bass voice. The laconicism of the initial intonation-thematic formula indicates that the composer thinks of it as a kind of philosophical thesis, which (by analogy with the practice of academic debates) should have been comprehensively elaborated in the process of further musical-textual unfolding. This approach to the development of thematic material is one of the characteristic features of the mature Vedel style, which, according to T. Husarchuk, is "... a complication of the musical composition associated with a fundamental change in the attitude of the composer to the verbal text. Music does not any more follow directly behind it, reflecting its deployment both in content and in compositional terms, and tends to develop independently" (Husarchuk, 1989, p. 83). This, according to the researcher, is predetermined "...the formation of a threephase section, which is based on a single line of text." The text is fully explained only in the expositional construction. In the second phase, a fragmentation takes place, 
often a multi-stage extraction and repetition of particular words and phrases. Here a motive-polyphonic approach, canonical technique, and, tone-harmonic development is applied. In the section with the exposition period, the development begins at the exposition stage - in the second sentence" (Husarchuk, 1989, p. 83).

Thus, the determining criterion of dramatic development in Vedel's work is not text and its adequate display by means of musical expansion, but an ideologicalshaped "algorithm" of the author's concept, based on the individual re-interpretation of the allegorical symbolism of the canonical text. To replace the external illustrations, the inner expression comes to the fore, associated with the individual vision of the artist. As a result, the functional relationship between the text and the music concepts changes qualitatively: the composer does not adjust the musical image to the specificity of the strophic discretion, but, in contrary, he adapts the text image and its compositional decision to the peculiarities of the musical organization. In this case, the allegorical theme of the psalms is reinterpreted individually and psychologically, often acquiring a new emotional color. This is especially evident in those works where the composer consciously seeks to emphasize the versatility of the interpretation of a certain figurative element, aiming to reveal its polysemantic nature.

On of such works is the famous concert \# 3 "Until, Lord, Forgetting Me" that without exaggeration can be named one of the masterpieces of both European and world choral music. Filled with paradoxical gravitas and at the same time mysterious innuendo, it seems to unfold before the listener both the micro and the macro-horizons of human being, giving artistic time and space profound philosophical meaning and functionality. This unfolding occurs through allegories of certain emotional states that are indirectly related to the whole spectrum of baroque religious-mystical issues: from symbols of the cross and the duality of being (in the context of the ChristianNeo-Platonic concept of the upper and lower worlds), represented by the intersection and contrasting antiphonic comparison of texture and timber layers (exposition of Part I of concert No. 3), to allegories of movement and 'confusion' of time and space (see Part II of concert No. 3). The elements of imagery, expressed through the compositional specificity of applying the tone-to-tonal ratios, play a decisive role in the dramatic intentional development.

An example would be a short four-stroke construction (see bars 29-32), in which the composer obviously sought to illustrate the textual development by an allegorical (major-minor) coloration given in direct accordance with the psalm text: "Diseases in the Heart of My Day and Night". Here, the first segment, presented in major, symbolizes the day, and the next that symbolizes the night is in minor. This is also to be seen in the peculiarities of the subtext of the final tonic-dominant construction, where the word 'day' falls on a major chord (dominant), and the word 'night' has a minor (tonic). In addition, such a major-minor solution to this episode may have been caused by the artist's desire to emphasize the ambiguity of the assessment of psychological states that are generalized in the allegorical image of the psalm text. After all, it is possible that Vedel could put different meanings in the word 'diseases', one of which is related to the purely negative staining that is commonly found in in the physical realities of the earth, while the other characterizes the state of bitter and sweet fatigue of the soul, almost driven mad by the search for harmony as a means of restoring of the lost godliness. 
Increasing the expressive capabilities of musical dramaturgy contributes to the widespread use by the composer of various techniques of musical and rhetorical expression, in particular, catabasis, anabasis, etc., which play an illustrative function, depicting a relief picture of mental confusion, and directed on different areas of the allegorically-shaped concept and expressed on several semantic levels: individual and social, upper and lower, real and mystical. At the same time, the principle of dialogic becomes of particular importance in the process of dynamic unfolding: the wave-like melodic movement in the ensemble construction "Until You Forget Me" corresponds to its modified mirror projection in the lower register. The rapid expressive rise of the melody line to the small sixth (anabasis) followed by the chromatized intonation recession (catabasis) is echoed by a structurally almost identical intonation phrase in the opposite timbre-register (see bars 5-6). The double alternation of contrasting ensemble episodes ends with the conclusive concluding construction, typical to the music-rhetorical traditions of the XVII-XVIII centuries, built on an undulating melodic movement filled with exalted pathetic.

Vedel's expressive desire for melodic reclamations and responsive structures, usually expressed by alternating different timbre compositions and textural relationships (ensemble - tutti), testifies to the composer was based on the oratorical principles of orthodox homiletics, where "... the emotional intensity of expression is achieved by sharp contrasts in all parameters, and these contrasts are short-lived, which further intensifies the intonation level" (Gerasymova-Persydska, 1997, p. 129). Thus the same intonation-rhythmic and textural relations act in different semantic values, depending on their role in the system of plot-allegorical architecture. In this regard, it is significant that the composer rethinks Western European means of polyphonic development from the standpoint of Ukrainian folk-song and canticle traditions. This, in particular, is clearly evident in the specifics of the textural solution of sequential layers, presented not monothematic, as in the ordinary canonical sequencing of the western type, but in the parallel movement of third and sixth second themes, which is characteristic to song-canticle paraphrase. In this case, the accent shifts significantly towards linearity, balanced by the chordal statement of the final cadence construction. This is especially evident in the detailed sequential construction, where the composer seems to summarize the figurative architectonics of the work. In its structural structure, the original features are traced that demonstrate the composer's artistic thinking on the deeply national layers of the intonation spectrum.

Unlike Western European baroque music, the sequential elements of which are universal in the compositions of different art schools and directions in the XVII-XVIII centuries. (both in the projection of German Protestantism: Schütz, Bach, Mannheim school, and in the layer of the Catholic religious and secular, and, in particular, instrumental tradition: Italy, France). Artemy Vedel, as well as Diletsky in his time, uses only the external form of sequential movement, filling it with purely national tone content. The semantics of motion and continuous temporal existence, to which the means of sequential development correspond, are here reproduced by Vedel not through the structural elements of Western technique of jubilation, with its multisegmented developed linearity of horizontal layers, as we can see e.g. in cantatas and passions by Bach, in particular in the introductory choir of "Passions on John", 
and through intonationally independent micro-elements, expressed in a multilayer diachronic projection.

All this creates the effect of flickering mosaic, "moving" density, where each detail is autonomous and at the same time interconnected with the other. Such a textural statement fully corresponds to the general dramatic conception of the Vedel's concert \# 3 with its hidden interaction of ideological parallels of human existence, reflecting the paradoxical dualism of the human being similar to the religious-philosophical aspect: human being as the center of the struggle of the divine and sinful principles (asceticism - hedonism), and in the aspect of social and historical, where the individual becomes an integral part of the ethnic group and its culture.

\section{Conclusions}

Summarizing these observations, we consider it necessary to reiterate that the interaction of these levels of the compositional process at certain stages of dramatic development is the result of reflective rethinking of the original canonical image and is directly dependent on the thoughts and moods of the composer at the time of realization of a particular creative concept.

This is due to the variety of means used by the composer in the process of composing text material. For example, in those cases where Vedel proceeds from the prerequisites of the dramatic development through a single storyline, the composer chooses as a basis the full text of the psalm. On the other side, where he seeks to reflect the multifaceted combination of different emotional states, he forms a text series on the principle of a kaleidoscopic synthesis of disparate psalm elements.

The presentation of multivariate algorithms of such ratios requires special scientific research that confirms the relevance of the chosen perspective of the study.

\section{References}

Askochenskiy, V.I. (1856). Kiev s drevneishim ego uchilishchem - Akademiei [Kiev with its oldest school - Academy [Monograph] (Vol. 2). Kyiv: Universitetskaia tipografiia [in Russian].

Gerasymova-Persydska, N.O. (1978). Khorovyi kontsert na Ukraini v XVII-XVIII st. [Choral concert in Ukraine in the XVII-XVIII centuries]. Kyiv: Muzychna Ukraina [in Ukrainian].

Gerasymova-Persydska, N.O. (1997). Kontserty i motety pokaianni - problema pov'iazannia tekstu i muzyky [Concerts and motets of repentance - the problems of linking the text with the music]. In Dukhovnyi svit barokko (pp. 12-33). Kyiv: Kurs.

Husarchuk, T. (1989). Tvorchist A.Vedelia i deiaki tendentsii rozvytku vitchyznianoho muzychnoho mystetstva XVIII st. [Works by A. Vedel and some trends in the development of domestic music art of the XVIII century]. In Ukrainska muzychna kultura mynuloho i suchasnosti v mizhnatsionalnykh zv'iazkakh (pp. 79-86). Kyiv [in Ukrainian].

Husarchuk, T. (1998). Tvory Artemiia Vedelia v konteksti khrystyianskykh tradytsii [Works by Artemy Vedel in the Context of Christian Traditions]. In I Vseukrainska Mizhnarodna Khrystyianska asambleia, Proceedings of the Scientific and Practical Conference. Kyiv: Publishing House of Ukrainian Orthodox Church of Kyiv Patriarchate [in Ukrainian]. 
Makarov, A. (1994). Svitlo ukrainskoho baroko [Light of Ukrainian Baroque]. Kyiv: Mystetstvo [in Ukrainian].

Petrushevskii, V. (1901). O lichnosti i tcerkovno-muzykalnom tvorchestve A. Vedelia (K istorii Kievo-akademicheskogo khora i kharakteristiki tcerkovnogo peniia $v$ Kieve $v$ kontce XVIII v.) [On the personality and church music works of A. Vedel (On the history of the KievAcademic Choir and Characteristics of Church Singing in Kyiv at the end of XVIII century)]. Trudy Kievskoi dukhovnoi akademii, 7, 382-396.

\section{СПЕЦИФІКА ОБРАЗНО-ДРАМАТУРГІЧНОЇ ВЗАЄМОДІЇ МУЗИЧНОГО І ВЕРБАЛЬНО-ТЕКСТОВОГО КОНЦЕПТІВ У ТВОРЧОСТІ АРТЕМІЯ ВЕДЕЛЯ}

\section{Ігор Тилик}

кандидат мистецтвознавства, доцент;

ORCID: 0000-0003-2896-631X; e-mail: tilik1968@ukr.net

Київський національний університет культури і мистецтв, Київ, Україна

\section{Анотація}

Мета роботи - висвітлити один із недостатньо досліджених аспектів веделезнавчої проблематики - специфіку співвідношення музичного і вербально-текстового концептів духовно-хорових творів А. Веделя у процесі їх образно-драматургічного розвитку.

Методологія дослідження ґрунтується на комбінованому застосуванні універсальних методів наукового пізнання, зокрема індукції, дедукції, історичного методу, культурологічної реконструкції, використання яких дає змогу оптимально розкрити сутність досліджуваної проблематики.

Наукова новизна дослідження полягає у тому, що вперше в сучасному музикознавстві розглянуто специфіку взаємодії музичного і вербально-текстового рядів у духовнохорових творах А. Веделя на перетині декількох евристичних проекцій, зокрема, музикознавчо-структуралістської, психологічної, релігійно-філософської.

Висновки. Творчість А. Веделя є складним і поліаспектним феноменом, сутність якого розкривається крізь призму відповідності вербально-текстового і музичного образу.

Ключові слова: співвідношення музичного і вербально-текстового концептів; духовно-хорова спадщина А. Веделя; релігійно-філософфський аспект; мистецьке сприйняття; алегорія; метафора 


\section{СПЕЦИФИКА ОБРАЗНО-ДРАМАТУРГИЧЕСКОГО ВЗАИМОДЕЙСТВИЯ МУЗЫКАЛЬНОГО И ВЕРБАЛЬНО-ТЕКСТОВОГО КОНЦЕПТОВ В ТВОРЧЕСТВЕ АРТЕМИЯ ВЕДЕЛЯ}

\section{Игорь Тылык}

кандидат искусствоведения, доцент;

ORCID: 0000-0003-2896-631X; e-mail: tilik1968@ukr.net

Киевский национальный университет культуры и искусств, Киев, Украина

\section{Аннотация}

Цель работы - изучить один из недостаточно исследованных аспектов веделезнавской проблематики - специфику соотношения музыкального и вербальнотекстового концептов духовно-хоровых произведений А. Веделя в процессе их образнодраматургического развития.

Методология исследования основывается на комбинированном применении универсальных методов научного познания, в частности индукции, дедукции, исторического метода, культурологической реконструкции, использование которых дает возможность оптимально раскрыть сущность исследуемой проблематики.

Научная новизна исследования заключается в том, что впервые в современном музыковедении рассмотрено специфику взаимодействия музыкального и вербальнотекстового рядов духовно-хоровых произведений А. Веделя на пересечении нескольких эвристических проекций, в частности, структуралистской, психологической, религиознофилософской.

Выводы. Творчество А. Веделя - сложный и полиаспектный феномен, сущность которого раскрывается сквозь призму соответствия вербально-текстового и музыкального образа.

Ключевые слова: соотношение музыкального и вербально-текстового концептов; духовно-хоровое наследие А. Веделя; религиозно-философский аспект; художественное восприятие; аллегория; метафора 